ANA LUÍSA COSTA ${ }^{1}$

DOI: 10.15290/CR.2019.24.1.04

Instituto Politécnico de Setúbal,

Portugal/Centro de Linguística

da Universidade de Lisboa

ORCID ID: 0000-0002-2529-4135

\title{
A contribution to the implicit/explicit debate on grammar learning: the case of contrast connectors
}

\begin{abstract}
In this paper, studies on language acquisition and development are seen as most relevant to grammar teaching and learning. Grammar teaching may be conceived as a process of building awareness of the language used from the earliest stages, as well as a process of scaffolding knowledge depending on later language development. In this perspective, grammar instruction (including curricular orientations) must take into account what belongs to spontaneous linguistic knowledge, and which linguistic knowledge crucially depends on the richness of discourse experiences at school. Data on the acquisition of contrast connectives in European Portuguese will support the idea that, even assuming that some innate principles rule early language acquisition, linguistic proficiency depends on language learning experiences accumulated through years of schooling. Furthermore, language development is not entirely accomplished by linguistic mastery: the ability to explain language through language may be considered a later stage of linguistic accuracy, associated with formal instruction.
\end{abstract}

Keywords: grammar learning, grammar teaching, implicit knowledge, explicit knowledge, metalinguistic knowledge, language acquisition, language development.

\section{Introduction}

This paper intends to contribute to the implicit/explicit debate on grammar learning and teaching through an example from language acquisition studies: the case of contrast connectives. The aim of this study is to discuss the nature of knowledge involved in grammar teaching and learning at school, within the field of educational linguistics and, in particular, within what may be referred to as Grammar Didactics.

1 Address for correspondence: Escola Superior de Educação do Instituto Politécnico de Setúbal Departamento de Ciências da Comunicação e da Linguagem Campus do IPS, Estefanilha 2914 - 504 Setúbal, Portugal. E-mail: ana.costa@ese.ips.pt 
In the first sections, the conflict between pedagogical approaches, as well as the concepts "implicit knowledge," "explicit knowledge" and "linguistic awareness" in Portuguese curricular guidelines are presented through the example of a grammar topic: contrast connective words.

Within a transmission model, grammar contents are mainly lists of terms and concepts to be "learned by heart," independent from children language experience. This traditional view on grammar teaching prevails in some teachers' practices and even remains in some Portuguese official syllabi (DGIDC 2009b, DGE 2015). Such a perspective in the official guidelines has been criticized by many authors, as, for instance, Rodrigues (2017) or Costa et al. (2018). Supporting an approach for grammar teaching where the starting point to build (explicit) knowledge about language is "in children's heads" (Hudson 1992: 10), the work by Duarte (1992, 1998), Hudson (1992) and Sim-Sim et al. (1997) had a strong influence in teacher training programs (see Freitas et al. 2007; Duarte 2008; Gonçalves et al. 2011), as well as in former and recent curricular guidelines (DGIDC 2009a; DGE 2018). Following this approach, grammar at school must take into account children linguistic (implicit) knowledge and use. Before being able to identify and classify specific linguistic structures and processes, children need to use it successfully for communication. Moreover, the ability to manipulate the target structures with some degree of consciousness is seen as the crux of the matter in grammar learning (Duarte 2010). Grammar at school is, then, conceived as a process of becoming aware of language knowledge and use (Duarte 2008; Sim-Sim et al. 1997).

These two extreme perspectives (the transmission model and the language awareness model), other theoretical gradients ${ }^{2}$, and teachers' concepts have made the history of Portuguese grammar teaching a "potpourri" of theoretical and methodological ideas. In this context, the concepts "implicit knowledge" and "explicit knowledge" are at stake and will benefit from some theoretical clarification (section 2). If the starting point for formal grammar learning should be the implicit linguistic knowledge children bring to school, comprising their early oral intuitions about language, studies on language acquisition and development may provide interesting cues to grammar teaching. This is the case of contrast connectives, explored in section 3.

In the final sections, methodologies for grammar teaching accounting for language development are explored. Again, from the Portuguese educational context, an example of Grammar Lab (see Duarte 1992, 1998, 2008) is presented, along with other methodological proposals, within an eclectic perspective in the field of Grammar Didactics (section 4). Summarizing, section 5 highlights some characteristics that mark the difference between the former grammar teaching proposals and the transmission model.

2 In the last decade, Portuguese language teachers had to deal with 4 different syllabi and curricular guidelines in basic education: National Curriculum for Basic Educations - Essential Skills (DEB 2001), a reference guideline until 2012; Portuguese Syllabi for Basic Education (DGIDC 2009a); Portuguese Syllabus and Goals for Basic Education (DGE 2015); Portuguese Essential Learning (DGE 2018). 


\section{The implicit/explicit debate}

The debate on the implicit and explicit language knowledge has filled thousands of pages on language learning research. It is easy to find summaries of this discussion in handbooks and other recent publications (see Spolsky \& Hult 2008; Ritchie \& Bhatia 2009; Rebuschat 2015). The concepts “implicit/explicit knowledge" may address very different issues. In Rebuschat (2015), Arthur Reber is remembered as the coiner of the term "implicit learning", which was the title of his MA thesis from the 60's. Opposing Chomsky's nativism theory, Reber's interest was focused on communication: "Children don't learn language; they learn to communicate. It's a social learning process" (Reber 2015: vii). For the author, "implicit" is explained as a euphemism of choice for "unconscious".

Following this framework, "implicit learning" means a process during which knowledge is acquired without instruction, and without subjects becoming aware of the knowledge acquired. On the other side, "the term explicit learning refers to a process during which participants acquire conscious (explicit) knowledge; this is generally associated with intentional learning conditions, e.g., when participants are instructed to look for rules or patterns" (Rebuschat 2015: xiii). In other words, in a comprehensive meaning, the implicit/explicit dichotomy may be understood in terms of the unconscious/conscious nature of the process of learning.

In this study, within the scope of Educational Linguistics, the implicit/explicit terms will specifically concern implicit/explicit grammar knowledge at school, in first language ${ }^{3}$ formal education contexts. Since the focus will be on the educational process, in the field of Grammar Didactics, the concepts of implicit/explicit grammar are used to describe both the kind of instruction that would better support grammar learning at school, as well as the nature of the linguistic knowledge involved in grammar learning. Recognizing that when children arrive at school, they already successfully use the grammar of their first language to communicate, the implicit/explicit dichotomy is also used to characterize the kind of spontaneous knowledge about grammar they bring to school, and the kind of knowledge about grammar which schooling needs to provide. As Hudson (1992: 10) states, "[w]e assume, then, that children already know (unconsciously) a great deal of grammar before they reach school." Naturally, children's spontaneous grammar is the grammar of their first oral language in family contexts, not necessarily the standard dialect teachers want them to use (Hudson 1992; Duarte 1998).

The origin of implicit and explicit grammar knowledge is explained differently according to differing linguistic schools. Yet, it is not the aim of this study to explore theoretical quarrels. It is assumed that educational linguistics is not an extension of the battlefield for linguistic theories. Instead, educational linguistics constitutes an autonomous research field that interacts with other subjects, including linguistics and its branches: "we seek then not to apply linguistics, but to derive from its many branches and from other fields that study language, the knowledge that will

3 In language education, much of the available literature on implicit and explicit learning is due to research on second language acquisition, being the work by Rod Ellis a reference on the focus-on-forms vs. focus-on-form debate, as well as in the discussion about the goals for explicit learning in focus-formed instruction. See, for instance, Ellis (2010). 
help in developing the language capacity of others" (Spolsky 1999: 2) ${ }^{4}$. Accordingly, this study tries to investigate different perspectives that are either in full agreement or almost in agreement and that may be helpful to educational goals.

Karmiloff-Smith (1992) proposes a model integrating results from nativism to Piaget's cognitivist psychology, in a coherent cocktail of theoretical explanations for linguistic, cognitive and social development:

one can attribute various innate predispositions to the human neonate without negating the roles of the physical and sociocultural environments and without jeopardizing the deep-seated conviction that we are special - creative, cognitively flexible, and capable of conscious reflection, novel invention, and occasional inordinate stupidity. (Karmiloff-Smith 1992:1)

Karmiloff-Smith's eclectic proposal has the advantage of illustrating a way to explain natural language acquisition as well as late linguistic development, and integrates concepts such as "implicit" and "explicit", while considering different degrees of awareness of explicit knowledge. Furthermore, the author indicates that what is special about the human child is the potential to analyze his own knowledge, including linguistic knowledge: "young children go beyond behavioral mastery, beyond fluent output and successful communication, to exploit the linguistic knowledge they have already stored. It is this that ultimately allows them to become little linguists." (Karmiloff-Smith 1992: 48)

As far as linguistic development is concerned, the representational redescription model (RR Model) is a process by which implicit linguistic information, unconscious and stored in the mind, becomes progressively explicit knowledge, available to the mind to be manipulated. The child's early internal representations are redescribed, leading to the emergence of conscious access to linguistic knowledge. The RR Model includes four levels at which knowledge is represented and rerepresented: (i) Implicit (I); (ii) Explicit-1 (E1); Explicit-2 (E2); and Explicit-3 (E3). The author also states that these diverse forms of representation are not age-related stages of linguistic development. They must be interpreted as parts of a reiterative process acting in different micro-domains and through the linguistic development span. A concrete example - the acquisition of French articles - illustrates how the RR Model accounts for the pathway from implicit to explicit linguistic knowledge. It is assumed that children are sensitive to nominal markers in language acquisition in general. The French language marks the definite/indefinite opposition with two different articles (le/un); the indefinite article has the same form as the numeral - masculine un and feminine une (the same description holds for Portuguese). In comprehension, as well as in production, children around the age of 3-years-old reach behavioral mastery for each function of this article/numeralform in separate contexts without mistakes, which may correspond to the implicit knowledge in level 1 representations. By the age of 5, data show sensitivity to differentiation of functions. For

4 Moreover, Spolsky claims that the relationship between linguistics and education is not a direct one: "while it is evident that linguistics is often relevant to education, the relation is seldom direct" (Spolsky 1978: 1). 
instance, children produce une voiture for 'a car' and une de voiture for 'one car'. This degree of sensitivity (also found in comprehension contexts) illustrates the redescription of stable internal knowledge in explicit internal data, in the E1 format. This internal representation explicitly marks the relationship between an identical form and different functions. However, representations in the E1 format are not yet knowledge available to conscious access. The passage from explicitly represented knowledge (E1) to consciously accessible knowledge and to verbal report is marked by the ability to give verbal explanations about language. First, children explain their linguistic guesses on the basis of real-world knowledge (eventually without verbal report, as it would be in level E2). With later development, children become able to refer explicitly to linguistic clues (that they had already been using unconsciously) to explain verbal facts, with verbal report. Again, an example from the noun determiners development is given in Karmiloff-Smith (1992: 59): "You must be talking to the boy because you said 'lend me the (stressed) car'".

All the different levels may be activated by the speaker (child or adult) for different goals, from level I for rapid and unconscious language use to explicit metalinguistic tasks with level E2/3. Although the RR Model postulates four levels, the author, indeed, only refers to three, without a clear distinction between level E2 and E3, both resulting from later development and involving conscious access, underpinning metalinguistic knowledge. ${ }^{6}$

A three-level model was proposed as well to support explicit grammar teaching in Portuguese curricula (Sim-Sim et al. 1997), where, differently from the transmission model, the knowledge of grammar should account for what develops naturally, through the language acquisition process, and what needs to be learned, and consequently, needs to be intentionally taught through formal education (see Duarte 1992; Sim-Simet al. 1997). In this model, a recursive and non-age-related process from (i) implicit linguistic knowledge and (ii) linguistic awareness, leading to (iii) explicit knowledge explains the raising of metalinguistic knowledge. The three concepts involved may be presently found in the Portuguese curricular guidelines. For a decade (2001-2012), in the Portuguese syllabi, Grammar was even termed "explicit knowledge of language".

Studies on late language acquisition and on Portuguese didactics support this approach for grammar teaching (see Costa 2010; Gonçalves et al. 2007; Freitas et al. 2010). Although "implicit knowledge" may be explained in terms of the nativist principles of the universal grammar (Costa et al. 2017a), in teacher training programs and curricular guidelines, the definition of each concept comes from consensual assumptions in linguistic theories. The idea of "implicit knowledge"

\footnotetext{
5 For a complete contextualization of this experiment, see Karmiloff-Smith (1992: 32-63).

6 Karmiloff-Smith (1992: 23) states: "I distinguish three levels of representational format: I, E1, and E2/3. For the present purposes, I do not distinguish between levels E2 and E3, both of which involve conscious access. No research has thus far been directly focused on the E2 level (conscious access without verbal report); most if not all metacognitive studies focus on verbal report (i.e., level E3)."

7 For instance, in the Portuguese language from 2009 syllabus (DGE 2009a), the subject contents were named Oral Comprehension, Oral Expression, Reading, Writing and Explicit Knowledge of Language.
} 
is associated, again, with the unconscious grammar knowledge that underpins language communication; it depends on spontaneous (acquisition and) learning. The "linguistic awareness" level is a stage of consciousness that, for instance, allows young children to play with rhymes or to be sensitive to ill-formed sentences. It is also the kind of linguistic capacity that is activated during the writing process (Duarte 2010). Finally, by "explicit knowledge" it is meant the reflective and systematized knowledge about the intuitive system that speakers know and use; it is also the metalinguistic knowledge of the rules that organize the oral and written language systems, and it always depends on intentional teaching and oriented learning (Duarte 2008).

To sum up, a crucial idea arises from the implicit/explicit debate: reaching the mastery of each aspect of linguistic knowledge through the spontaneous learning process is not the end of the language development pathway. A level of metalinguistic capacity (seen as the E2/3 level in Karmiloff-Smith 1992), or the "explicit knowledge of language" (in Sim-Sim et al. 1997) guarantees a very human characteristic of language: the capacity to use language to explain and think about language. This capacity is associated with late language development and with formal instruction contexts, where grammar teaching should play a meaningful role (see Karmiloff-Smith 1992; SimSim et al. 1997; Menyuk and Brisk 2005; Berman 2004; Costa et al. 2017a). ${ }^{8}$

\section{Linguistic knowledge and grammar contents: the case of contrast connectives}

In the previous section, a relationship between what is known about language acquisition and development and explicit grammar knowledge was made. The case of contrast connective words will now be used as an example of how grammar teaching designs should take into account what children already know when they enter school, and what needs to be fostered through intentional instruction, in order for grammar learning to become a meaningful activity.

\subsection{Notes on methodological issues}

Data on the acquisition and development of European Portuguese contrast connective words come from different studies on the:

a. Production of the first connective words in early oral spontaneous speech of three children aged 1; 5.9 to 3; $11.12^{9}$ - Corpus Santos (2006), Costa et al. (2008).

b. Oral comprehension, elicited production and written production of contrast connectives by children and adolescents aged 9; 3.13 to 16; 2.09 in school contexts (Costa 2010).

c. Written production of contrast connectives in early argumentative writing by children from $2^{\text {nd }}$ grade and $4^{\text {th }}$ grade (Costa et al. 2017b).

8 Metalinguistic knowledge, associated with school experiences, as an important step in language development is also present in the idea of "linguistic literacy" (Berman 2004) and in the description of maturational changes in language development through school ages (Menyuk \& Brisk 2005).

9 Representation of a child's age in number of years; months days. 
d. The effects of explicit knowledge on contrast connectives in argumentative writing skills of $9^{\text {th }}$ grade students (Costa 2010).

As far as the educational research is concerned, data were collected within a naturalistic approach (Hyland 2002). Oral and written tasks were integrated into regular classroom activities, and tutored by classroom teachers, with whom the researcher established a protocol. Written texts were transcribed in the CHILDES format, in CHAT, in order to get a semi-automatized analysis of connective uses (frequencies and concordances), and text-oriented research was followed (Hyland 2002). Table 1 summarizes the data sample selected to illustrate the case of contrast connectives.

Table 1 -Data sample

\begin{tabular}{|l|l|l|l|}
\hline STUDY & WRITERS & OPINION TEXTS & WORDS \\
\hline $\begin{array}{l}\text { Costa, Carreto \& Cerqueira } \\
(2017 \mathrm{~b})\end{array}$ & $\begin{array}{l}37 \text { students }\left(2^{\text {nd }}\right. \\
\text { grade) }\end{array}$ & 49 & 1533 tokens \\
\hline \multirow{2}{*}{ Costa $(2010)$} & $\begin{array}{l}24 \text { students }\left(4^{\text {th }}\right. \\
\text { grade })\end{array}$ & 24 & 3888 tokens \\
\cline { 2 - 4 } & $\begin{array}{l}55 \text { students }\left(9^{\text {th }}\right. \\
\text { grade })\end{array}$ & 110 & 19806 tokens \\
\hline
\end{tabular}

Regarding the study referred to in d), on the relationship between grammar teaching and writing skills, the design integrated (i) a pre-test, which consisted of a diagnosis for written argumentation skills; (ii) a Grammar Lab on contrast connectives, included in a writing project on argumentative texts; (iii) a post-test, again with an argumentative written task. Grammar Lab will be explained in section 4 .

\subsection{Contrast connectives at school}

Connective words are an example of typical grammar content. How are Portuguese syllabi designed for the teaching of contrast connectors? Table 2 shows this content at each level.

Table 2. Contrast connectives in Portuguese syllabi

\begin{tabular}{|c|c|c|c|c|c|c|c|c|}
\hline \multirow[t]{2}{*}{ Grade } & \multicolumn{3}{|c|}{$\begin{array}{l}\text { Primary school } \\
\text { (Age 6-9) }\end{array}$} & \multicolumn{2}{|c|}{$\begin{array}{l}\text { 2nd cycle } \\
\text { (Age 10-11) }\end{array}$} & \multicolumn{3}{|c|}{$\begin{array}{l}\text { 3rd cycle } \\
\text { (Age 12-14) }\end{array}$} \\
\hline & \begin{tabular}{l|l}
1 & 2
\end{tabular} & 3 & 4 & 5 & 6 & 7 & 8 & 9 \\
\hline $\begin{array}{l}\text { Writing } \\
\text { Contents }\end{array}$ & & & \multicolumn{3}{|c|}{$\begin{array}{l}\text { Textualization: } \\
\text { discourse connectors }\end{array}$} & & & \\
\hline $\begin{array}{l}\text { Grammar } \\
\text { Contents }\end{array}$ & & & & & & $\begin{array}{l}\text { - Connective } \\
\text { adverbs: } \\
\text { contudo, } \\
\text { porém...'('yet, } \\
\text { however..') } \\
\text { - Coordination: } \\
\text { adversative } \\
\text { conjunctions: } \\
\text { mas ('but') }\end{array}$ & $\begin{array}{l}\text { Subordination: } \\
\text { concessive } \\
\text { conjunctions: } \\
\text { embora, apesar } \\
\text { de, aindaque... } \\
\text { ('although, } \\
\text { in spite of, } \\
\text { nevertheless..') }\end{array}$ & \\
\hline
\end{tabular}


Regarding grammar instruction, in what seems to be implicit instruction, there is a general reference to discourse connectors integrated into Writing Contents from $4^{\text {th }}$ to $6^{\text {th }}$ grade. Explicit instruction only arrives in the 3rd cycle, after students reach the age of 12 . It should be noted that the two semantic classes of contrast connectors - adversative and concessive ${ }^{10}$ - are taught separately in $7^{\text {th }}$ and $8^{\text {th }}$ grade. Building the bridge between these two classes, which is a wise reflection to avoid connector repetitions in written texts, depends on teachers' linguistic training.

There is no reference to implicit or explicit instruction about any kind of connective words in the first three years of primary school. Besides, there is no orientation to the sort of work to be done in the $9^{\text {th }}$ grade. Above all, there is no intended articulation between Writing and Grammar: tackling this area, or not, remains up to teachers' discretion. Therefore, teachers need pedagogical insights on how grammar learning works.

\subsection{Contrast connectives knowledge and development}

In a pedagogy where the starting point must come from students early and spontaneous experiences, one should consider what children know about contrast connectors before school and during school years. This is when looking at the (implicit) grammar they bring to school may provide meaningful clues to pedagogy. How does the study of the acquisition of contrast connectors help Grammar Didactics? What do pre-school children know about contrast connectors before they reach school?

In a study on the early acquisition of connectors in European Portuguese (Costa et al. 2008; Costa 2010), mas ('but') was found between the first connective words beginning from the third year of life. The order established for the subset of connective words studied is represented in (1). In (2) an example from an early use of mas ('but') with a contrastive meaning is given. ${ }^{11}$

(1) e $>$ mas $>$ porque $>$ se 'and' 'but' 'because' 'if'

(2) CHI: Não, é uma canoa ve(r)melh(a). Mas não é do pai. (Tomás, 2; 7.13) 'No, it's a red canoe. But it is not father's [canoe].'

At about the same age, the same order was found in Dutch, in a study by Evers-Vermeul (2005), represented in (3) and (4).

(3) en > maar > toen > want

'and' 'but' 'then' 'because'

(4) CHI: Slagboomgaatniet open. Maarhijkanwelerdoor. (Peter, 2; 8.22)

'Barrier does not open. But he can do it.'

10 For a comprehensive study on contrast, see Rudolph (1996).

11 The first production of mas ('but') in the Corpus Santos (2006) emerged at the age of 2;1.7. 
A similar order of acquisition had been established for English, in Diessel (2004), a study on the acquisition of complex sentences from where example (6) was taken.

(5) and $>$ because $>$ so $>$ but $>$ when $>$ if

(6) CHI: But... it's raining here. (Peter 2; 6)

For all three languages, the adversative connective is acquired before the age of 3 , and it is the only connective word used in spontaneous oral speech to express contrast for the first three years of life.

However, the word but is not the single open resource used to express contrast between propositions. When do children begin to use other contrast connectives? When do subordination concessive connectives become available?

In his early work, Piaget (1924) concludes that before the age of 11/12 the full comprehension of these connectors is not accomplished. The idea that concessive structures are acquired later is expressed in different works, even though recent data found concessive uses (comprehension and production) by children younger than Piaget's informants. According to Diessel, in English, there are "no concessive clauses marked by although or whereas" before the age of $5^{12}$ (Diessel 2004: 157) and the same goes for European Portuguese: no concessive connector was found in the corpus Santos (2006) before the age of 4 .

However, between then and the beginning of primary school, the first concessive word must emerge, since some children in $4^{\text {th }}$ grade already understand successfully one or two concessive connectors. In Figure 1, the rate of right answers in an oral comprehension task is represented: students from $4^{\text {th }}$ grade reached results above $50 \%$.

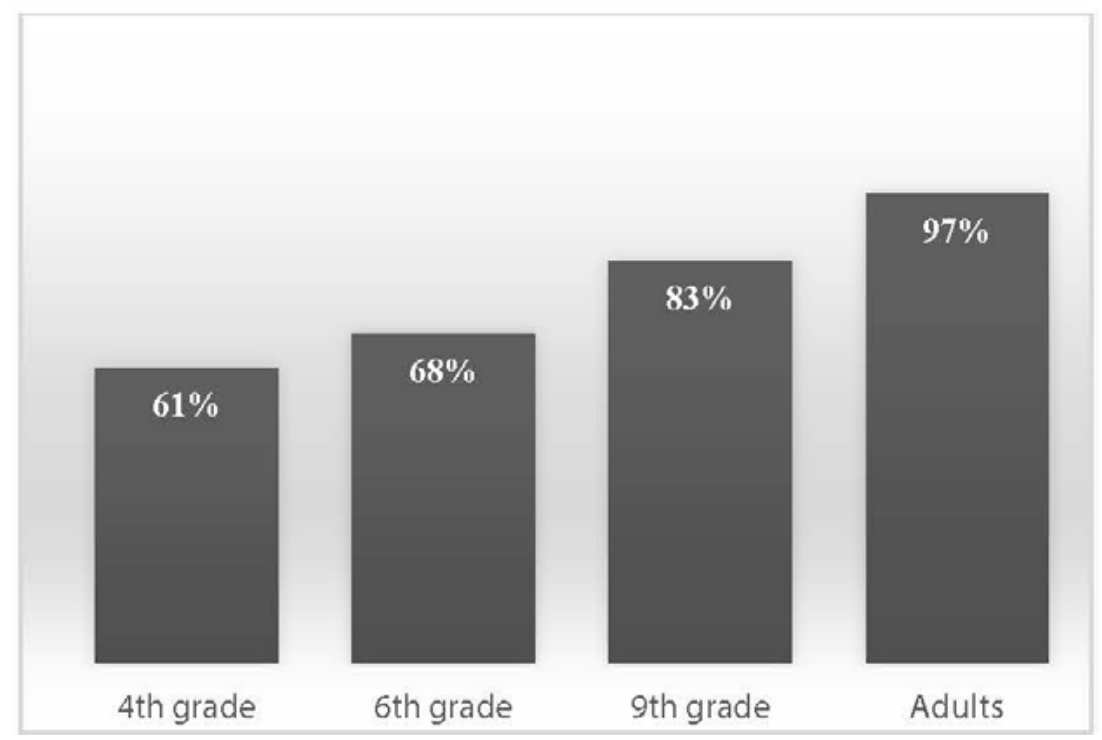

Figure 1. Concessive connectives oral comprehension task (Costa 2010)

12 Diessel (2004) studied five English-speaking children aged from 1;8 to 5;11. 
Still, not all children use, e.g., understand and produce, the concessive connective words assessed. In Costa (2010), in a study with children from different school cycles and a control group of educated adults, considering the same oral comprehension task, the comparison of hits shows that the comprehension of concessive connective words is not entirely accomplished by the end of primary school (39\% of wrong answers). Oral comprehension of concessive connectives grows throughout the years of schooling.

The same curve may be observed in an elicitation task (Fig. 2), where children had to build sentences with concessive connectives. In this task, students had results below $60 \%$ by the end of primary school.

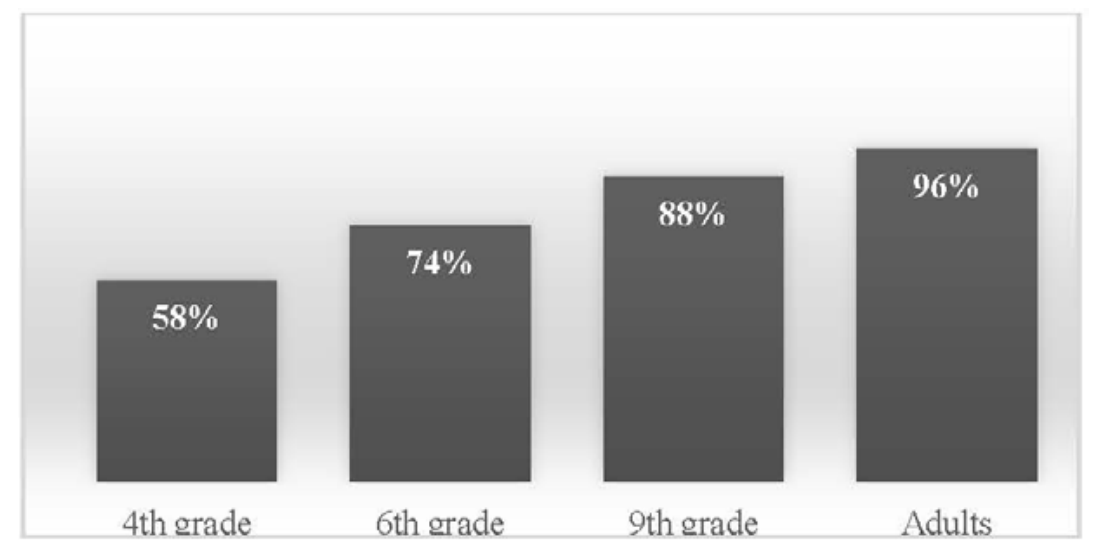

Figure 2. Concessive connectives elicited production task (Costa 2010)

Looking now at the use of adversative and concessive connectors in opinion written texts in $2^{\text {nd }}$ grade, and at the end of primary school, in $4^{\text {th }}$ grade (Fig. 3), contrast is almost exclusively expressed by the adversative connector mas ('but'), as it should be expected because concessive knowledge is then still under development.

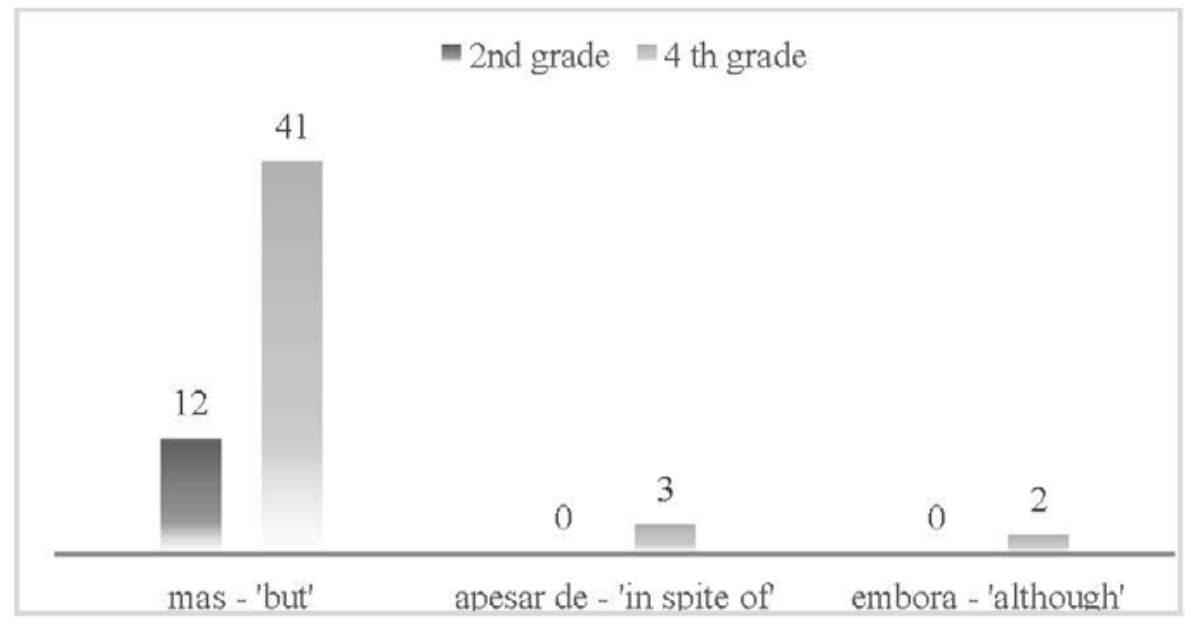

Figure 3. Adversative and concessive written production

(Costa, Carreto \& Cerqueira 2017b) 
What pedagogical conclusions should we draw from this data? Does this mean that it is useless to teach the adversative connective because it is spontaneously learned by the third year of life and it is, somehow, unconsciously used in early written speech? Does this mean that it is useless to teach concessive connectives since they will be naturally learned? Or, on the contrary, does this mean that only concessive connectives should be explicitly taught at school, since but is spontaneously acquired? More data, on formal writing performances, should be taken into account.

Considering the use of adversative and concessive connectors in the $9^{\text {th }}$ grade, when students already have comprehension skills and elicited production reaches levels similar to adult behavior (see Fig. 1 and 2), the implicit knowledge of concessive connectors is not being mobilized to improve writing: teenagers in a written task used almost exclusively the same connector as they had been using in spontaneous oral speech since they were two years old (Fig. 4).

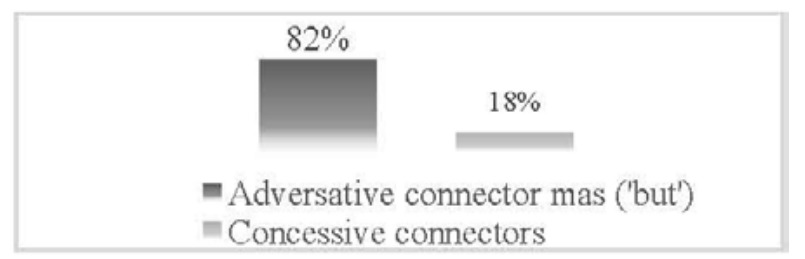

\section{Figure 4 . Written production $-9^{\text {th }}$ grade, pre-test (Costa 2010$)$}

Some empirical evidence supports the idea that explicit grammar instruction may enhance the use of concessive connectors. In a case study with $9^{\text {th }}$ grade students, after a Grammar Lab (see section 4) on the explicit functioning of adversatives and concessive sentences, in the written production post-test task the use of concessive connectors increased: as it is shown in Figure 5, students used mas ('but') fewer times and structured more sentences with diversified concessive connective words.

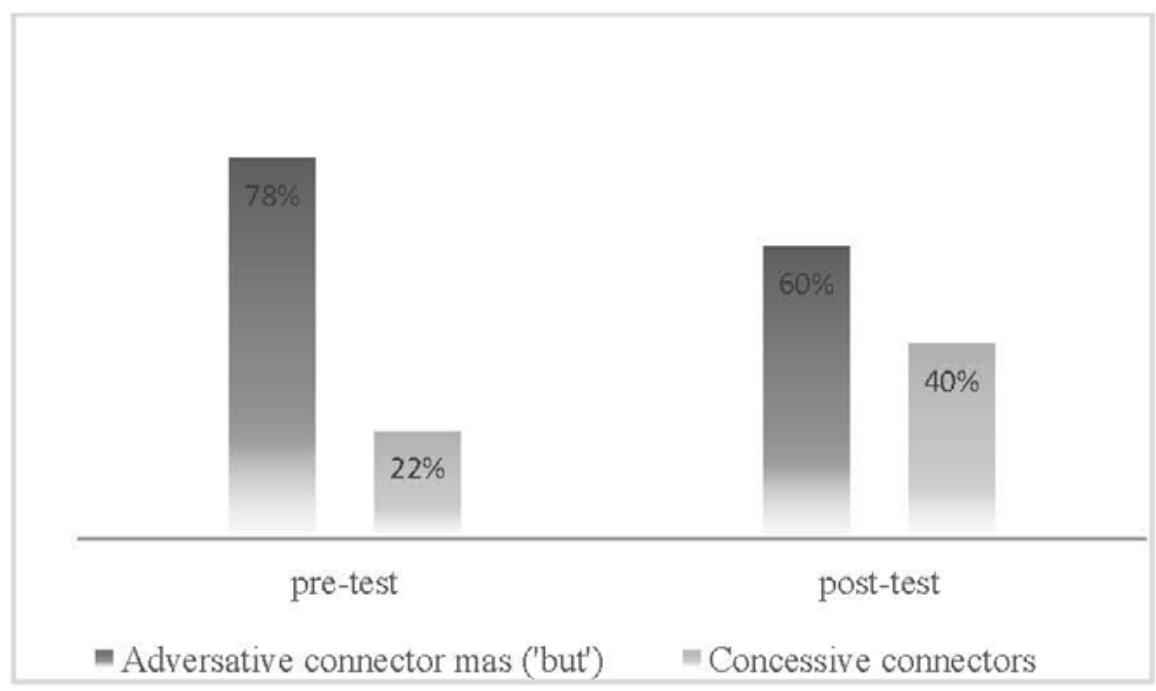

Figure 5. Written production - $9^{\text {th }}$ grade, pre-test, and post-test (Costa 2010) 
In the post-test task, textual complexity, including better syntactic fluency, semantic and pragmatic density, as well as lexical diversity were improved in written argumentation.

Grammar, conceived as a process of becoming aware of implicit linguistic resources, may achieve two critical goals: (i) scaffolding the awareness of linguistic structures available since early acquisition (for instance, in the case of adversative connectives) and (ii) enhancing the development of linguistic structures acquired later (e.g., the use of concessive connectives in formal oral and written registers). Furthermore, there is a third good reason for grammar teaching according to this approach: it improves metalinguistic reasoning. For instance, the same ${ }^{\text {th }}$ grade students had better results in a classification task than their colleagues in a control group who studied grammar in a traditional way.

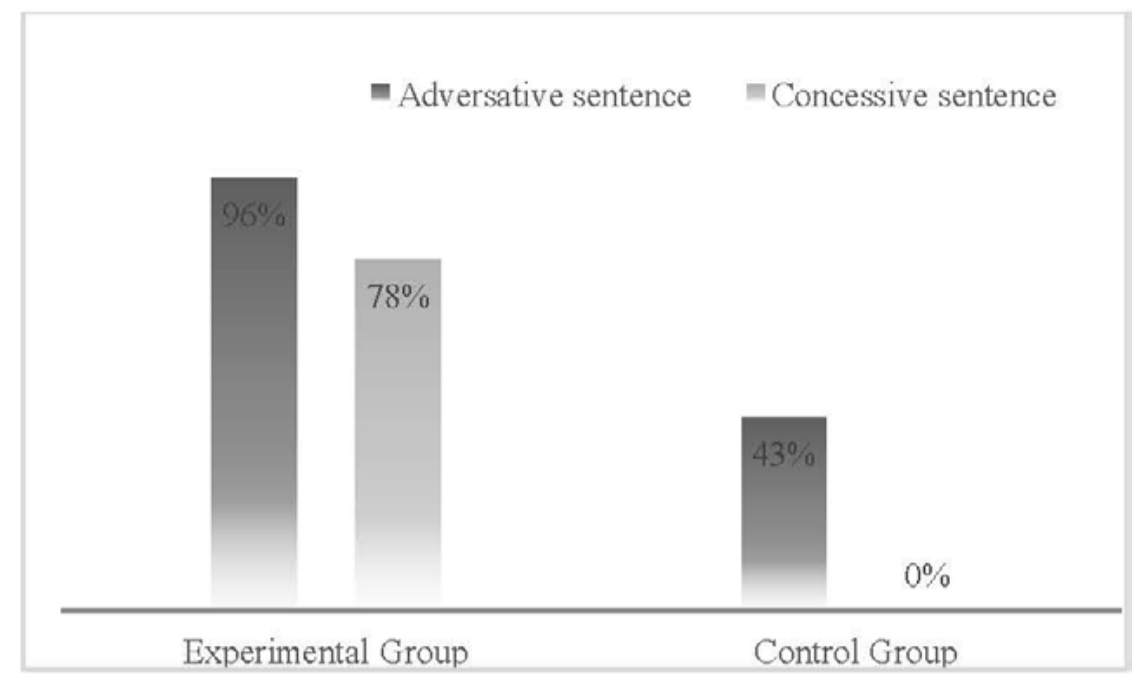

Figure 6. Classification task - $9^{\text {th }}$ grade, experimental group, and control group (Costa 2010)

As previously mentioned, in the study referred to, the properties of adversative and concessive connectives were taught within a Grammar Lab methodology in order to enhance "linguistic awareness" and build "metalinguistic knowledge".

\section{Grammar teaching approaches - grammar as a reflective activity}

Could the picture in Figure 5 be the result of traditional grammar teaching instruction ${ }^{23}$ In such an approach, as it seems to be usual in some teachers' practices (DGIDC 2008b), adversative and concessive connectors are meant to be identified and classified, as declarative contents, in the $7^{\text {th }}$ and $8^{\text {th }}$ grades, by applying the syllabus prescription directly. In a different way, in the Gram-

13 Costa (2010) included a control group with students from a class where a traditional approach for grammar teaching was followed. Those students achieved lower results in the post-test written task than students from the experimental classes. 
mar Lab (Costa 2010), students were involved in a contextualized grammar reflection that was integrated into a written project (Jolibert (coord.) 1988). Before they had to jump onto classifications, students were involved in data manipulation and description to discover functioning rules through their own linguistic experiments which involved metalinguistic reasoning.

In addition to Grammar Lab, other methods fit into such a Grammar Didactics concept. Two broad types of strategies of grammar teaching approaches will be referenced. Both types mark a difference from traditional grammar instruction, and both may account for language development while achieving metalinguistic knowledge.

In the first type of Grammar Lab (see Duarte 1992, 1998; Hudson 1992) or Linguistic Inquiries (see Honda et al. 2010; O’Neil 2010), while studying grammar, students are invited to reflect with some degree of autonomy over linguistic properties, starting from their intuitive knowledge and from their own language experiences. Metalanguage is only introduced whenever it makes sense for the students' learning pathway.

The first step of a Grammar Lab is a question or problem. In the case of contrast connectives (Costa 2010), the question was raised from the revision of the student's written texts: how to avoid the repetition (Fig. 4) of the word mas ('but')? Then, students were invited to observe data and raise hypotheses. Data were previously organized in minimum pair paradigms, built with adversative and concessive sentences. Oriented through teacher's questioning, hypotheses about the functioning of different kinds of contrast sentences were raised by students. Attention was focused on properties such as verb mood, sentence position, connective position, pragmatic effects and semantic similarities and differences between sentences with different adversative and concessive connectives. In the third step of this Grammar Lab, students' first hypotheses were validated by the manipulation of new sentences. The generalization of these hypotheses into grammar rules allowed for the introduction of meaningful metalanguage: classes of sentences and conjunctions were brought into metalinguistic reflection.

One of the last steps - training - was done during a text revision task, in order to transform grammar knowledge into writing skills. Finally, the assessment was made in two different ways: with a traditional grammar test (Fig. 6) and with the analysis of a written task (Fig. 5).

As mentioned above, regarding these types of approaches, Hudson claims that linguistic data, the material that nourishes didactic activities, are easy to obtain because they are "in children's heads" (Hudson 1992: 10). Implicit knowledge is made explicit through questioning. Scientific reasoning, with similar steps to a scientific experiment, is introduced, and grammar at school is conceived as a reflective activity.

This type of grammar teaching approach is not committed to one specific linguistic theory, which is an excellent example of the indirect relationship between linguistic theories and educational linguistics (see section 2). The pedagogical insight underpinning both Grammar Lab and Linguistic Inquiries is Brunner's questioning and discovery learning. Hudson (1992: 47) explains that "grammar is taught primarily by discovery-learning" since the "pupils are exploring what they know already, which is probably a non-standard dialect.” In Wayne O’Neil's words (2010: 26), refer- 
ring to one of his projects, the "pedagogy of the linguistic part of the curriculum was to be Socratic as influenced by Jerome Bruner's spiral of learning." The interaction between the students and their teacher guiding the questioning is a central pedagogical issue. Finally, Duarte $(1998,2008)$ advocates that one of the goals of explicit grammar teaching must be the development of metacognitive skills, as the logical reasoning embedded in the scientific exploration of linguistic data, with steps moving from observing, comparing and analyzing, inferring principles, generalizing... In summary, the author claims: "I use grammar in the sense of reflective knowledge!" (Duarte 1993: 53)

In the last decades, empirical research on the pedagogical effects of Grammar Lab as a classroom activity has shown the benefits of grammar reflection with writing and reading tasks (see Batalha 2018; Costa 2010). A Grammar Lab on contrast connectives, for instance, should be in an instructional sequence of argumentative writing. Furthermore, Rodrigues and Silvano (2010) maintain that Grammar Lab's positive effects crucially depend on its discourse contextualization. In other words, there is a place for autonomous metalinguistic reflection, granted that it is integrated into meaningful discourse participation. Oral communication, reading, and writing, in social interactions at school, provide the opportunities to build metalinguistic knowledge.

At this point, it is worth noting that there is a triangular relationship between language use, linguistic development, and metalinguistic reflection. Explicit grammar teaching, by itself, is not enough to increase language development. In the words of Nippold (2004), students must actively be engaged in metalinguistic behavior, which plays a key role in later linguistic acquisitions. Moreover, this comes from students' participation in complex discourse situations. Consequently, social interaction in a school context plays a critical issue in this matter:

With its emphasis on literacy, schooling plays a critical role in later language development. As discussed above, education provides the school-age child or adolescent with the necessary exposure to complex and low-frequency words, multilexemic expressions, and syntactic structures. This occurs when students read or listen to complex discourse. Circumstances that motivate students to actively analyze what they hear and read - to engage in metalinguistic behavior - also play a key role in the developmental process, along with the opportunity to use the new words and structures for their own communicative purposes. (Nippold 2004: 5)

In the second type of grammar teaching approaches, "metalinguistic knowledge emerges from social interaction" (Camps 2014: 29), being that classroom interaction is a crucial context for learning (Fontich 2014). Collaborative reasoning among learners underpins metalinguistic reflection in classroom activities.

Metalinguistic knowledge is defined as the capacity that everyone has "to take language as the object of observation and the referent of discourse" (Camps \& Milian 1999: 6). In addition, Debra Myhill appeals to the notions of "explicit" and "conscious" to explain metalinguistic knowledge as the "explicit bringing into consciousness of an attention to language as an artefact, and the con- 
scious monitoring and manipulation of language to create desired meanings grounded in sociallyshared understandings" (Myhill 2011: 250).

Within the sociocultural Vygotskyan framework, metalinguistic knowledge is developed at school through metalinguistic activity (the capacity to use language to refer to and explain language). Metalinguistic activity may be manifested by different means in the developmental pathway: procedural (for instance, restatements, repetitions...), with spontaneous verbalizations (with everyday language) or using scientific language, e.g., grammatical terms and concepts (see Camps \& Millan 1999).

Regarding the place of grammar teaching at school, while recognizing the interdependence of language use and metalinguistic activity, it is assumed that "giving a functional value to grammatical knowledge is not incompatible with studying the grammatical system itself" (Ribas et al. 2014: 12). Above all, in a balance between linguistic and education, linguistic theories are not applied to classroom activities: there is a reconfiguration of linguistic concepts for a Pedagogical Grammar.

Through instructional language learning sequences (grammar learning sequences, but also writing sequences), the natural capacity to use language to explain language is the starting point to build explicit grammar knowledge (see Camps \& Zayas 2006). An instructional sequence may be implemented in different grades, gradually following more structured steps. As it is mentioned in Fontich (2014: 16), these instructional sequences are in line with "guided induction", where "the teacher explains a learning target and designs a sequence of activities that lead students to observe, identify and manipulate linguistic material in order to find the answer to a problem (linked to standard writing, for example)".

Metalinguistic activity has been the object of comprehensive classroom research, focusing predominantly on two domains: grammar notions and terms taught at school and metalinguistic reasoning that emerges from textual production processes, mostly in collaborative writing (see Fontich 2014, 2016, 2018). The seminal work by Anna Camps (1994) on argumentative texts and logical connectors, including contrast connectors, is an excellent example of a metalinguistic activity that underpins linguistic and discourse development with teenagers from $7^{\text {th }}$ and $8^{\text {th }}$ grades. ${ }^{14}$ As a final point, Anna Camps concludes:

Learning grammar notions and the possibility that they can serve as operative instruments to improve language usage requires a reflective approach in language and grammar teaching that helps students in the process that spans from information to generally applicable concepts and from these concepts to the possibility of using them when constructing and understanding discourses. (Camps 2014: 38)

14 Camps (1994: 281-285) found textual improvement in text superstructure, as well as in the diversity of logicalargumentative connectives after an instructional argumentative writing sequence. The author states that there is a need for further work on the characteristic forms of the argumentative text. 


\section{Final remarks}

Research on language acquisition contributes to educational linguistics with an insight of what children linguistically know before entering school, and presents a different view from a tabula rasa perspective or a chaotic perspective of early linguistic knowledge. A traditional approach for grammar teaching, where terms and concepts are learned by heart, independently from the students' previous knowledge, may be characterized through the words by Vygotsky:

direct teaching of concepts is impossible and fruitless. A teacher who tries to do this usually accomplishes nothing but empty verbalism, a parrot-like repetition of words by the child, simulating a knowledge of the corresponding concepts but actually covering up a vacuum. (Vygotsky 1934: 150)

Grammar instruction guidelines must take into account what children and adolescent already (implicitly or unconsciously) know, in order to intentionally promote meaningful grammar learning. In the case of contrast connectives, the use of metalanguage to identify and classify it may fall in the vacuum without the awareness that 'but' is available in a child's speech long before 'although' or 'nevertheless'. Furthermore, the emergence of concessive connectives depends on the opportunity to use them in the interactions granted by school discourse. Again, Vygotsky refers to similar data (performances with causal and concessive connectives) to explain the emergence of scientific concepts: "A child of that age [ $2^{\text {nd }}$ grade] can learn to use because consciously since by then he has already mastered its spontaneous use. Not having mastered although in the same way, he naturally cannot use it deliberately in his 'scientific' thinking" (Vygotsky 1934-1986: 191). Regarding this, teachers should consider that awareness on the use of mas ('but') may be enhanced earlier, in the textual revision process, for instance, before classifying adversative and concessive connectives in $7^{\text {th }}$ and $8^{\text {th }}$ grade (Table 2). Moreover, the diversification of contrast connectives (including the emergence of concessive connectors) may be improved through argumentative discourse.

Grammar teaching approaches that take into account language development (from mastery to metalinguistic knowledge), such as Grammar Lab, Linguistic Inquiries, or Instructional Sequences for metalinguistic activity, may have fundamental theoretical differences, but, contrary to the traditional method, they all claim that grammar is a reflective activity.

Finally, as a reflective activity, grammar instruction must aim at:

i. Scaffolding the awareness of linguistic structures available since early acquisition;

ii. Enhancing the development of linguistic structures acquired later;

iii. Engaging students in metalinguistic reasoning, from implicit to explicit and metalinguistic knowledge. 


\section{References}

Batalha, J. 2018. Relações entre o conhecimento explícito da língua e a competência de leitura. (Doctoral dissertation) Retrieved from RUN, Nova University of Lisbon http://hdl. handle. net/10362/43439

Berman, R. 2004. Between emergence and mastery. The long development route of language acquisition. In: R. Berman (ed.), Language Development across Childhood and Adolescence, 9-34. Amsterdam/Philadelphia: John Benjamins.

Camps, A. 1994. L'ensenyament de la composicióescrita. Barcelona: Editorial Barcanova.

Camps, A. 2014. Metalinguistic activity in language learning. In: T. Ribas, X. Fontich \& O. Guasch (eds.), Grammar at School. Research on Metalinguistic Activity in Language Education, 25-41. Brussels: Peter Lang.

Camps, A. \& Milian, M. (eds.). 1999. Metalinguistic Activity in Learning to Write. Amsterdam: Amsterdam University Press.

Camps, A. \& Zayas, P. (cords.). 2006. Seqüències didàctiques per aprendre gramàtica. Barcelona: Grao.

Costa, A. 2010. Estruturas contrastivas: desenvolvimento do conhecimento explícito e da competência de escrita. (Doctoral dissertation). Retrieved from University of Lisbon http://hdl.handle. net/10451/2216.

Costa, A., Alexandre, N., Santos, A. \& Soares, N. 2008. Efeitos de modelização no input: o caso da aquisição de conectores. In: A. Santos \& S. Frota (orgs.), Textos Selecionados do XXIII Encontro da Associação Portuguesa de Linguística, 131-142. Lisboa: APL, Colibri.

Costa, A., Costa, M. A. \& Gonçalves, A. 2017a. Consciência linguística: aspetos sintáticos. In: M. J. Freitas \& A. L. Santos (eds.), Aquisição de língua materna e não materna: Questões gerais e dados do português, 409-438. Textbooks in Language Sciences 3. Berlin: Language Science Press. http://langsci-press.org/catalog/book/160.

Costa, A., Carreto, V. \& Cerqueira, S. 2017b. 'E essa é a minha opinião'. Para o estudo da emergência da escrita argumentativa, 51-73. Revista da Associação Portuguesa de Linguística. N. 3 https://ojs.apl.pt/index.php/rapl/article/view/24.

Costa, A., Rodrigues, S. \& Sebastião, I. 2018. Para que serve a didática? In: C., L. Grosso, L. R. \& S. Poças (orgs.) O Tempo dos Professores, 811-827. Porto: CIIE. FPCEUP.

Direção Geral de Educação 2015. Programa e metas curriculares de Português do ensino básico. Lisboa: DGE. ME.

Direção Geral de Educação 2018. Aprendizagens essenciais de Português para o ensino básico.Retrieved from http://www.dge.mec.pt/aprendizagens-essenciais-ensino-basico__(10 October 2018)

Direção Geral de Inovação e Desenvolvimento Curricular. 2009a. Programas de Português do Ensino Básico. Lisboa: DGIDC.ME.

Direção Geral de Inovação e Desenvolvimento Curricular. 2009b. Posição dos Docentes Relativamente ao Ensino da Língua Portuguesa. Lisboa: DGIDC.ME. 
Diessel, H. 2004. The Acquisition of Complex Sentences. Cambridge: Cambridge U.P.

Duarte, I. 1992. Oficina gramatical: contextos de uso obrigatório de conjuntivo. In: DelgadoMartins et al. Para a Didáctica do Português. Seis Estudos de Linguística. Lisboa: Colibri.

Duarte, I. 1993. O ensino da gramática como explicitação do conhecimento linguístico. In: L. F. Barbeiro, E. Fonseca, C. Nobre \& E. Machado (eds.), Ensino Aprendizagem da língua portuguesa. Leiria: ESEL-IPL.

Duarte, I. 1998. Algumas boas razões para ensinar gramática. In:A Língua Mãe e a Paixão de Aprender. Actas, 110-123. Porto: Areal.

Duarte, I. 2008. O Conhecimento da Língua: Desenvolver a Consciência Linguística, 49-60. Lisboa: PNEP. DGIDC. ME.

Duarte, I. 2010. Sobre o conceito de consciência linguística. In: M. J. Freitas, A. Gonçalves, A. \& I. Duarte (cords.) Avaliação da consciência linguística. Aspectos fonológicos e sintácticos do português, 11-16. Lisboa: Colibri.

Ellis, R. 2008. Explicit Form-Focused instruction and second language acquisition. In: B. Spolsky \& F. M. Hult (eds.), The Handbook of Educational Linguistics, 437-455. Oxford: Wiley-Blackwell.

Evers-Vermeul, J. 2005. The Development of Dutch Connectives: Change and Acquisition as Windows on Form-Function Relations. Utrecht: LOT.

Fontich, X. 2014. Grammar and language reflection at school. Checking out the whats and the hows of grammar instruction. In: T. Ribas, X. Fontich \& O. Guasch (eds.), Grammar at School. Research on Metalinguistic Activity in Language Education, 225-283. Brussels: Peter Lang.

Fontich, X. 2016. L1 Grammar instruction and writing: metalinguistic activity as a teaching and research focus. Language and Linguistic Compass 10(5): 238-254.

Fontich, X. \& García-Folgado, M. J. 2018. Grammar instruction in the Hispanic area: The case of Spain with attention to empirical studies on metalinguistic activity. Special issue: Working on grammar at school in L1 education: Empirical research across linguistic regions. L1 - Educational Studies in Language and Literature 18: 1-39.

Freitas, M. J., Alves, D. \& Costa, T. 2007. O Conhecimento da língua: desenvolver a consciência fonológica. Lisboa: PNEP.DGIDC.ME.

Freitas, M. J., Gonçalves, A. \& Duarte, I. (cords.). 2010. Avaliação da consciência linguística. Aspectos fonológicos e sintácticos do português. Lisboa: Colibri.

Gonçalves, F., Guerreiro P. \& Freitas, M. J. 2011. Conhecimento da língua. Percursos de desenvolvimento. Lisboa: PNEP.DGIDC.ME.

Honda, M., O’Neil, W. \& Pippin, D. 2010. On promoting linguistics literacy: Bringing language science to the English classroom. In: K. Denham \& A. Lobeck (eds.), Linguistics at School: Language Awareness in Primary and Secondary Education. Cambridge: Cambridge University Press, 175-188.

Hyland, K. 2002. Teaching and Researching Writing. London: Longman. MacWhinney.

Hudson, R. 1992. Teaching Grammar. A Guide for the National Curriculum. Oxford: Blackwell.

Jolibert, J. (coord.) 1988. Former des Enfants Producteurs de Textes. Paris: Hachette-Écoles. 
Karmiloff-Smith, A. 1996. Beyond Modularity. A Developmental Perspective on Cognitive Science. Cambridge, Mass: MIT Press/Bradford Books.

MacWhinney, B. 2000. The CHILDES Project: Tools for Analyzing Talk ( $3^{\text {rd }}$ edition). Mahwah, NJ: Lawrence Erlbaum Associates.

Myhill, D. 2011. The Ordeal of Deliberate Choice': Metalinguistic Development in Secondary Writers. In: V. Berninger (ed.), Past, Present, and Future Contributions of Cognitive Writing Research to Cognitive Psychology, 247-274. New York: Psychology Press/Taylor Francis Group.

Nippold, M. 2004. Research on later language development. In: R. Berman (ed.), Language Development across Childhood and Adolescence, 1-8. Amsterdam/Philadelphia: John Benjamins.

O’ Neil, W. 2010. Bringing linguistics into the school curriculum: not one less. In: K. Denham \& A. Lobeck (eds.), Linguistics at School. Language Awareness in Primary and Secondary Education. Cambridge: Cambridge University Press.

Piaget, J. 1993 [1924]. Le Jugement et le Raisonnement Chez l'Enfant. Paris: Delachaux et Niestlé.

Reber, A. 2015. Foreword. In: P. Rebuschat (ed.), Implicit and Explicit Learning of Languages, viiviii. Amsterdam/Philadelphia: John Benjamins.

Rebuschat, P. (ed.). 2015. Implicit and explicit learning of languages. Amsterdam/Philadelphia: John Benjamins.

Ribas, T., Fontich, X. \& Guasch, O. 2014. Introduction. In: Grammar at School. Research on Metalinguistic Activity in Language Education,11-24. Brussels: Peter Lang.

Ritchie, W. \& Bhatia, T. K. 2009. The New Handbook of Second Language Acquisition (2 ${ }^{\text {nd }}$ edition). Bingley: Emerald Group.

Rodrigues, S. 2017. O ensino do Português nas primeiras décadas do século XXI. In:Conselho Nacional de Educação, Lei de Bases do Sistema Educativo: balanço e prospetiva - Volume I, 247291. Lisboa: Conselho Nacional de Educação.

Rudolph, E.1996. Contrast: Adversative and Concessive Relations and their Expressions in English, German, Spanish, Portuguese on Sentence and Text Level. Berlin/NewYork: Walter de Gruyter.

Silvano, P. \& Rodrigues, S. 2010. A Pedagogia dos Discursos e o Laboratório Gramatical no ensino da gramática. Uma proposta de articulação. In: A. M. Brito (org.). Gramática: História, Teorias, Aplicações, 275-286. Porto: Fundação Universidade do Porto - Faculdade de Letras.

Santos, A. L. 2009 [2006]. Minimal Answers. Ellipsis, Syntax and Discourse in the Acquisition of European Portuguese. New York: John Benjamins Publishing.

Sim-Sim, I., Duarte, I. \& Ferraz, M. J. 1997. A Língua Materna na Educação Básica. Lisboa: DEB. ME.

Spolsky, B. 1978. Educational Linguistics: an Introduction. Rowley, MA: Newbury House.

Spolsky, B. 1999. Introduction to the field. In: B. Spolsky (ed.), Concise Encyclopedia of Educational Linguistics,1-6. Oxford: Elsevier.

Spolsky, B. 2008. Introduction: what is Educational Linguistics? In: B. Spolsky \& F. Hult (eds.), The Handbook of Educational Linguistics, 1-9. Oxford: Wiley-Blackwell. 
Vygotsky, L. 1986 [1934]. Thought and Language. Translation newly revised and edited by Alex Kozulin. Cambridge, Massachusetts: MIT Press.

$* * *$

Ana Luísa Costa is Assistant Professor at Higher Education College of the Polytechnic Institute of Setúbal (Portugal) and researcher at the University of Lisbon Linguistics Centre (CLUL). She teaches different courses of Didactics and Linguistics in training programs for pre-school and primary school teachers. Her research is focused on Early Literacy and Educational Linguistics. 